SCENES OF INSTRUCTION 



\title{
SCENES OF INSTRUCTION
}

\author{
a memoir : Michael Awkward
}

DUKE UNIVERSITY PRESS Durham \& London 1999 
(C) 1999 Duke University Press

All rights reserved

Printed in the United States of America

on acid-free paper $\infty$

Designed by C. H. Westmoreland

Typeset in Dante with DIN Neutzeit Grotesk

Bold Condensed display by Keystone Typesetting, Inc.

Library of Congress Cataloging-in-Publication Data

appear on the last printed page of this book. 
for Carol 

What I have lost is not a Figure (the Mother), but a being; and not a being, but a quality (a soul): not the indispensable, but the irreplaceable.-ROLAND BARTHES, Camera Lucida

My father ... had gone to the city seeking life, but ... [his] life had been hopelessly snarled in the city, . . that same city which had lifted me in its burning arms and borne me toward alien and undreamed-of shores of knowing. -RICHARD WRIGHT, Black Boy

We're all consequences of something. Stained with another's past as well as our own. Their past in my blood. - GAYL JONES, Corregidora

Travel folders call you

So do your memories -PHOEBE SNOW, "Isn't It a Shame?"

It was time to put all of the pieces together, make coherence where before there had been none. -TONI MORRISON, The Bluest Eye 
